\title{
Ethylene Production and Growth Accerelation in the Seedlings of Dwarf and Semidwarf Mutants Derived from a Cultivar of Rice (Oryza sativa L.)
}

\author{
Yoshu Yoshiba ${ }^{\dagger}$, Fumihiko Sekiguchi* and Hikoyuki Yamaguchi ${ }^{\dagger+}$ \\ Laboratory of Radiation Genetics and Chemical Mutagenesis, Faculty of Agriculture, \\ University of Tokyo \\ 1-1-1, Yayoi, Bunkyo-ku, Tokyo 113, Japan \\ *Department of Biology, Faculty of Science, Japan Women's University \\ 2-8-1, Mejirodai, Bunkyo-ku, Tokyo 113, Japan
}

Received March 12, 1993

\begin{abstract}
The rate of seedling growth of the semidwarf mutant cultivar Reimei and the dwarf mutant line, Fukei 71 were found to be much faster than their original cultivar Fujiminori. Such rapid early growth of the dwarf and semidwarf mutants was significantly inhibited by the treatment with the ethylene synthesis inhibitor, aminoethoxyvinylglycine (AVG). For example, with $25 \mu M$ of $A V G$ treatment the elongation was inhibited by $36 \%$ and $41 \%$ during the growth of Reimei and Fukei 71 seedlings, respectively, as compared with $13 \%$ for that of Fujiminori. Gas chromatography showed that ethylene production in Reimei and Fukei 71 were about 2.5 and 7.1-fold higher than that of Fujiminori, respectively. It was suggested that the stimulation of the growth in dwarf and semidwarf mutants might be derived from the increased ethylene production.
\end{abstract}

Key Words: dwarfness, Oryza sativa Linne, ethylene production, seedling growth, aminoethoxyvinylglycine, AVG, ethylene precursor, growth accerelation

\section{Introduction}

Ethylene, which is the simplest olefin and exists in gaseous state under normal physiological conditions, was known to regulate many aspects of plant growth, development and senescence. All plant tissues are capable of producing ethylene, although the production rate is generally low. In particular, ethylene is significantly produced during the certain stages of

\footnotetext{
† Present address: Advanced Research Laboratory, Hitachi, Ltd., Hatoyama, Saitama-Pref. 350-03, Japan.

t† Present address: Department of Radiology, Komazawa Junior College, 1-23-1, Komazawa, Setagaya-ku, Tokyo 154, Japan.
}

growth, such as ripening of fruits, abscission of leaves and senescence of flowers. The pathway of ethylene biosynthesis is characteristic, common to all higher plants, and has been well known that methionine is the biological precursor of ethylene. Methionine is converted to ethylene via the following biosynthetic route: methionine $-S$-adenosylmethionine (SAM) - 1aminocyclopropane-1-carboxylic acid (ACC) ethylene. In the ethylene biosynthesis, ACC synthase ( $S$-adenosylmethionine methylthioadenosine-lyase, EC 4. 4.1.14), which catalyzes the conversion of SAM to ACC, has been reported to be the rate-limiting enzyme ${ }^{1)}$. On the other hand, ethylene production can also be promoted with a variety of external factors, such 
as mechanical wounding, various environmental stresses and several chemicals including auxin and other regulators ${ }^{2)-4}$.

Aharoni et al. ${ }^{5)}$ reported that dwarf cultivars of both bean and wheat matured earlier and produced more ethylene than normal plants, showing the descrete difference in ethylene production during the younger plant stage.

In this paper, we report that two kinds of radiation-induced mutants, dwarf and semidwarf, produce more ethylene than the normal, parent cultivar during the seedling phase, and that the seedling growth of the mutants is effectively inhibited by the treatment of ethylene synthesis inhibitor.

\section{Materials and Methods}

\subsection{Plant material}

The semidwarf mutant cultivar Reimei, the dwarf mutant line, Fukei 71 and the original cultivar Fujiminori were used. The mutants, Reimei and Fukei 71 were induced by ${ }^{60} \mathrm{Co}$ gamma-ray-exposure of 20 and $30 \mathrm{kR}$, respectively.

\section{$2 \cdot 2$ Plant growth}

After husks were removed, the seeds were soaked with $70 \%$ ethanol and $2 \%$ sodium hypochlorite solutions for 5 and $30 \mathrm{~min}$, respectively, and then rinsed with sterile water. Seeds were germinated either under white fluorescent lamps (5 000 lux) or without light at several different temperature between 20 and $40^{\circ} \mathrm{C}$ in $6 \mathrm{~cm}$ Petri-dishes of flat bottom test tubes containing $4 \mathrm{ml}$ or $1 \mathrm{ml}$ of sterile distilled water.

\subsection{AVG treatment}

Seeds of normal and dwarf rice were germinated in the presence of 5,25 and $50 \mu \mathrm{M}$ AVG. Degree of growth inhibition by AVG was measured by the seedling height after 3 day-treatment. In the case of ethylene mea- surement, the seeds were treated with $25 \mu \mathrm{M}$ AVG alone.

\section{$2 \cdot 4$ Determination of ethylene}

Ethylene productions were measured for 3 $\mathrm{ml}$ gas samples collected with a syringe from the headspace of each $25 \mathrm{ml}$ capped vial. The collected gas was injected into a Hitachi 26330 type gas chromatograph with a flame ionization detector and a capillary column. Flow rate of the carrier gas, nitrogen, was $30 \mathrm{ml}$ per minute, and the column temperature was $70^{\circ} \mathrm{C}$. The retention time of ethylene determined by using authentic ethylene was $2.36 \mathrm{~min}$.

\subsection{Ethylene precursor treatment}

Seeds of normal, semidwarf and dwarf rice were germinated in sterile solutions containing $100 \mu \mathrm{M}$ of ethylene precursors; L-methionine (Met), S-adenosy 1-L-methionine (SAM) or 1-aminocyclopropane-1-carboxylic acid (ACC). The effect of ethylene precursor treatments were evaluated from the height of 4 day-old seedling.

\section{Results}

3-1 Differential growth of normal and dwarf seedlings

Figure 1 shows the growth of normal, semidwarf and dwarf seedlings germinated at several different temperatures between 20 and $40^{\circ} \mathrm{C}$ for $70 \mathrm{~h}$. Optimal temperature for the seedling growth was about $32^{\circ} \mathrm{C}$, as generally observed in rice plant, in different to the light conditions or plant types, normal, semidwarf or dwarf. Interestingly, it was found that the seedling growth of dwarf and semidwarf forms, Fukei 71 and Reimei, was greater than the normal rice, Fujiminori, at the optimal temperature. For instance, in comparison with Fujiminori, the seedling growth of Reimei and Fukei 71 were 1.1-fold (not significant) and 2.4-fold (significant at $1 \%$ level) higher at $32^{\circ} \mathrm{C}$, respectively. 


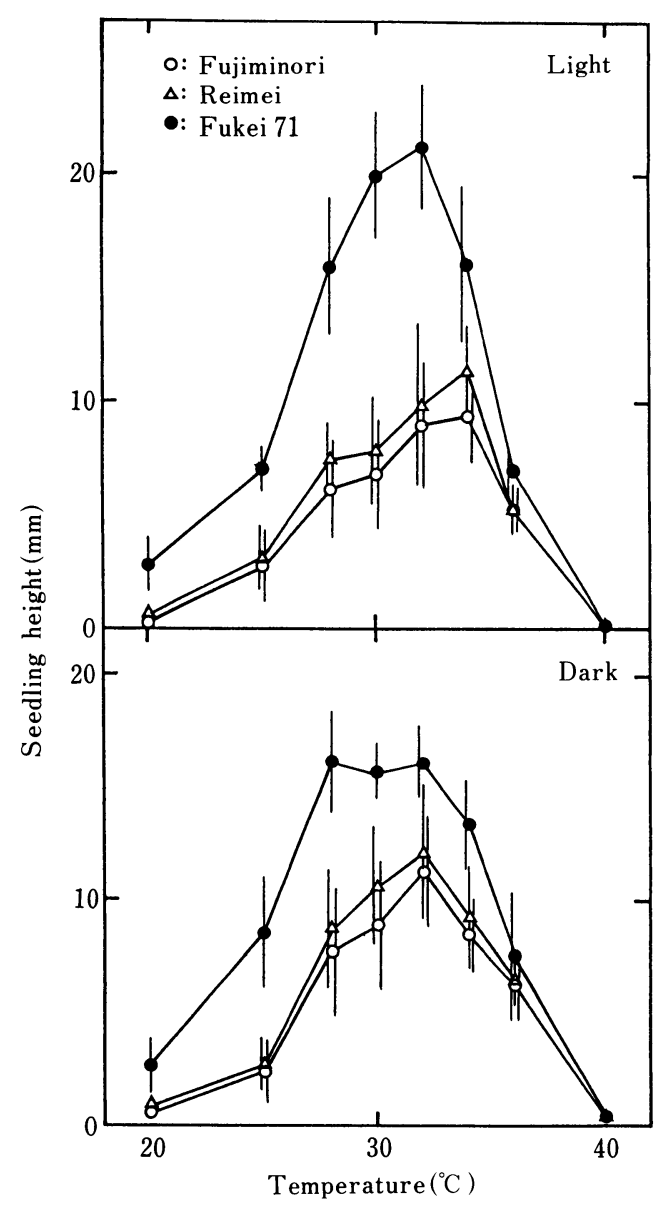

Fig. 1 Effect of temperature on the growth of normal and dwarf rice seedlings. Each $6 \mathrm{~cm}$ Petri-dish contained 30 seeds and $4 \mathrm{ml}$ of sterile water. The Petri-dishes were kept in the light or in dark at several different temperatures. Measurements were performed after $70 \mathrm{~h}$. The values are the means with standard error of three repeated experiments.

In Fig. 2, a sequential growth up to 8 days of normal and dwarf seedlings was shown. Growth of dwarf and semidwarf rice, Fukei 71 and Reimei, was seemed to be accelerated compared with that of normal rice, Fujiminori.

\subsection{Effects of AVG treatment}

Normal Fujiminori, semidwarf Reimei and dwarf Fukei 71 rice seeds were soaked in 5, 25 and $50 \mu \mathrm{M}$ solutions of AVG and allowed to germinate.

Figure 3 shows the degree of inhibition in seedling growth after AVG treatment, compared with the corresponding untreated control. The growth inhibition by AVG treatment was higher in Fukei 71 and Reimei as compared with Fujiminori. When treated with 25 $\mu \mathrm{M}$ of AVG, the growth inhibition of Fujiminori was only $12.5 \%$ however in the case of Fukei 71 and Reimei, the inhibition was $41.3 \%$ and $35.9 \%$ respectively. Growth inhibition over $50 \%$ was observed in all seedlings with the treatment of $50 \mu \mathrm{M}$ AVG. However, when AVG concentration was reduced to 5 $\mu \mathrm{M}$, no growth inhibition in all of three types was observed.

\subsection{Ethylene production and effect of AVG} treatment

Ethylene production was investigated on the $3 \mathrm{rd}$ day of germination. Table 1 shows the amount of ethylene produced by dwarf rice seedlings and the inhibition rate of AVG treatment on ethylene production. The volumes of ethylene produced were $70.5 \mathrm{nmol}$ in Fujiminori, $174.7 \mathrm{nmol}$ in Reimei and $498.4 \mathrm{nmol}$ in Fukei 71 (significant at $1 \%$ level). Reimei and Fukei 71 produced 2.5- and 7.1-times higher amount of Fujiminori, respectively. Therefore, AVG treatment effectively inhibited the ethylene production of Reimei and Fukei 71.

\subsection{Effect of ethylene precursor treatment}

Figure 4 shows the effect of ethylene precursor treatment. The effect of the treatment was measured by seedling height on the 4th day. The growth accerelation by Met and SAM treatment was not recognized in all three types. However, the growth rate of normal, Fujiminori and semidwarf, Reimei 


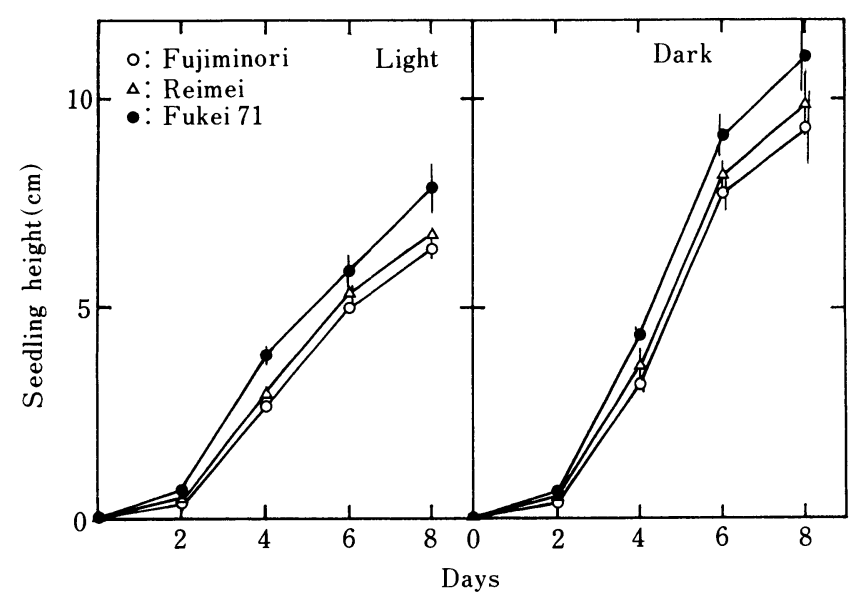

Fig. 2 Growth difference between normal and dwarf rice seedlings.

Each test tube of flat bottom contained 5 seeds and $1 \mathrm{ml}$ of sterile water. The test tubes were used with 3 per one variety or strain. The test tubes were kept in the light or in dark at 32 ${ }^{\circ} \mathrm{C}$. The values are the means with standard error of four repeated experiments.

were accerelated by ACC treatment. The extents of the growth rate were 1.5-fold in Fujiminori and 1.2-fold in Reimei compared with that of the respective controls.

\section{Discussion}

Semidwarfness of Reimei and dwarfness of Fukei 71 are the characteristics derived from a single recessive gene, located at different loci, and all the other characteristics, except for reduced culm length, were similar to those of the original variety, Fujiminori ${ }^{6}$.

It was found, however, that the seedling height of the dwarf rice was higher than the normal one both in vitro and in intact plant, which tendency did not change under the light conditions (Figs.1 and 2).

$\mathrm{Ku}$ et al. ${ }^{7)}$ reported that the growth rate of

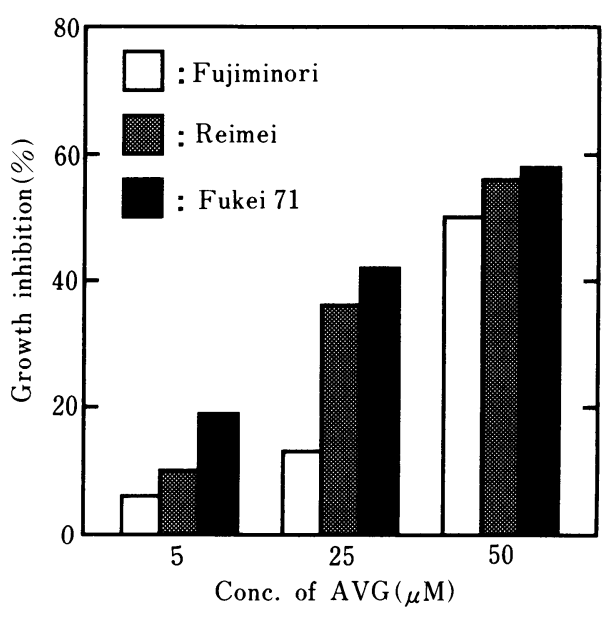

Fig. 3 Effect of AVG on the growth of normal and dwarf rice seedlings. In each $6 \mathrm{~cm}$ Petri-dish, 30 seeds were incubated in $4 \mathrm{ml}$ of sterile AVG solution. The Petri-dishes were kept in the light at $32{ }^{\circ} \mathrm{C}$. Measurements were performed on the 3 rd day after imbibition. The values are the means of four repeated experiments. rice coleoptiles was accerelated by low concentrations of ethylene. In this experiment, it was observed that the ethylene production of Reimei and Fukei 71 were about 2.5- and 7.1fold of Fujiminori, respectively. We tried to treat rice seeds with an inhibitor of ethylene production, AVG, which was known to inhibit ethylene production in a wide variety of plant tissues $^{8)-10}$. It was recognized that AVG significantly inhibited the growth of Reimei and Fukei 71 as compared with that of the parent plant, Fujiminori (Fig. 3 and Table 1). The optimal concentration of AVG was found to be about $25 \mu \mathrm{M}$ in growth inhibition.

As shown in Fig. 4, the growth of seedling in Fujiminori and Reimei was accerelated only by ACC treatment. The result suggested that the addition of ACC accelerated ethylene synthesis in Fujiminori and Reimei, however, the growth of Fukei 71 seedlings was not effected by the treatment of the ethylene precursors. Some precur- 
Table 1 Effect of AVG on ethylene production in normal and dwarf rice seedling

Each vial of $25 \mathrm{ml}$ contained 10 seeds, $0.7 \mathrm{ml}$ of sterile solution containing $25 \mu \mathrm{M}$ AVG. The vials were kept in the light at $32^{\circ} \mathrm{C}$. Measurements were performed after $72 \mathrm{~h}$. The values are the means of four repeated experiments.

\begin{tabular}{llrcc}
\hline \multirow{2}{*}{$\begin{array}{l}\text { Varity } \\
\text { or strain }\end{array}$} & Character & \multicolumn{3}{c}{$\begin{array}{c}\text { Ethylene production } \\
\text { (nmol/10 seedlings) }\end{array}$} \\
\cline { 3 - 5 } & & Control & $\begin{array}{c}\text { AVG treat- } \\
\text { ment }\end{array}$ & $\begin{array}{c}\text { Inhibition } \\
(\%)\end{array}$ \\
\hline Fujiminori & Normal & 70.5 & 12.6 & 82.2 \\
Reimei & Semidwarf & 174.7 & 8.5 & 95.1 \\
Fukei 71 & Dwarf & 498.4 & 7.6 & 98.5 \\
\hline
\end{tabular}

sors of ethylene synthesis, especially ACC, might be accumulated in Fukei 71 seedling.

In generally, causes of dwarfism have been studied mainly from the point of hormonal deficiencies, especially of gibberellins. And these dwarfs have been reported gibberellin mutants as they became phenotypically normal after exposed to exogenous $\mathrm{GAs}^{11)-13)}$.

On the other hand, Kitano et al. ${ }^{14)}$ observed that the expression of the dwarf gene of Fukei 71 was not altered by $\mathrm{GA}_{3}$ treatment, and concluded that the dwarf gene was not involved in the metabolism on GAs biosynthesis. Furthermore, semidwarf mutant cultivar Reimei and dwarf mutant line Fukei 71 are isogenic to their original cultivar, Fujiminori, except for the semidwarf or dwarf gene ${ }^{6}$.

Therefore, the results suggest that dwarf and semidwarf mutant genes of Fukei 71 and Reimei respectively, are involved in the ethylene synthesis system.

\section{Acknowlegement}

We are grateful to Prof. Dr. Y. Futsuhara of Faculty of Agriculture, Nagoya University for providing the seeds of Fukei 71 .

\section{References} rice seedlings.

Each test tube of flat bottom contained 6 seeds and $1 \mathrm{ml}$ of sterile precursor solution $(100 \mu \mathrm{M})$. Three test tubes were used per one variety or strain. The test tubes were kept in the light at $32{ }^{\circ} \mathrm{C}$. Measurements were performed on the 4 th day after imbibition. The values are the means of triplicate experiments, and the bars indicate the standard deviation.

Abbreviations : Cont, control ; Met, methionine; SAM, S-adenosylmethionine; ACC, 1-aminocyclopropane-1-carboxylic acid.
1) Yang, S. F. and Hoffman, E. N. : Ann. Rev. Plant Physiol., 35, 155-189 (1984)

2) Lieberman, M. : ibid., 30, 533-591 (1979)

3) Yoshii, H. and Imaseki, H. : Plant Cell Physiol., 22, 369-379 (1981)

4) Métraux, J. P. and Kende, H. : Plant Physiol., 72, 441-446 (1983)

5) Aharoni, Y., Phan, C. T. and Spencer, M. : Can. J. Bot., 51, 2243-2246 (1973)

6) Futsuhara, Y.: Gamma Field Symp., 7, 87109 (1968)

7) Ku, H.S., Suge, H., Rappaport, L. and Pratt, K. H. : Planta (Berl.), 90, 333-339 
(1970)

8) Adams, D. O. and Yang, S. F. : Proc. Natl. Acad. Sci. USA, 76, 170-174 (1979)

9) Yu, Y.B. and Yang, S. F. : Plant Physiol., 64, 1074-1077 (1979)

10) Ross, J. J. and Reid, B. J. : ibid., 67, 673-679 (1986)

11) Phinney, B. O.: "Plant Growth Regulation",
(Klein, M. R. ed.), pp. 489-501, Iowa State University Press, Ames, Iowa (1961)

12) Suge, H. and Murakami, Y. : Plant Cell Physiol., 9, 411-414 (1968)

13) Gotoh, N. : ibid., 11, 355-359 (1970)

14) Kitano, H., Futsuhara, Y. and Nakada, T. : Jpn. J. Breed., 33, 138-147 (1983)

\title{
要 旨
}

\section{イネ矮性突然変異体のエチレン生産とその生長促進効果}

\author{
吉羽洋周, 関口文彦*, 山口彦之** \\ (侏立立製作所基礎研究所 $350-03$ 埼玉県比企郡鳩山町赤沼 2520 \\ *日本女子大学理学部 113 東京都文京区目白台 2-8-1 \\ **駒沢大学短期大学部 154 東京都世田谷区駒沢 1-23-1
}

フジミノリのガンマ線照射で得られた半矮性突然変異品種のレイメイと矮性突然変異系統のふ系 71 号 は, 成熟期にフジミノリと比較するとそれぞれ約 $15 \mathrm{~cm}$ と $45 \mathrm{~cm}$ の節間伸張が抑制される。しかし, 発 芽初期生長を比較すると逆に, 矮性であるレイメイ, ふ系71号の方が正常型のフジミノリよりあ旺盛な 生長を示すことが認められた。そこでこれらの矮性イネが何に起因して生長促進を示すのか調べた結 果, 高いエチレン生産能を有することが判明した。

エチレン生産量は，穎を除去した各種子 10 粒を $25 \mathrm{ml}$ サンプル瓶内で無菌的に発芽させ，その気相を 採取し，ガスクロマトグラフィにより同定し定量した。発芽 3 日目のエチレン量は, フジミノリで 70.5 $\mathrm{nmol}$, レイメイで約 2 倍の $174.7 \mathrm{nmol}$, ふ系 71 号では7.1倍の $498.4 \mathrm{nmol}$ であった。

これらのエチレン生産は，エチレンの生成阻害剤であるアミノエトキシビニルグリシン（AVG）処理 で抑制され，とくに矮性イネにおいて効果的であった。

さらに，エチレンの先駆体であるメチオニン（Met），S-アデノシルメチオニン（SAM） および 1-ア ミノシクロプロパン-1ーカルボン酸 (ACC) 処理に対する生長反応を調べた結果, ACC 処理にのみ矮性 型と正常型で異なった反応を示した。この反応は, フジミノリで最も高く（対照の約1.5倍）, レイメイ ではわずかにみられ (約1.2倍)，ふ系71号では生長を促進するような反応はみられなかった。以上の結 果から，これらの矮性イネがエチレンの生合成系に関する突然変異体であることが示唆された。 